\title{
A Sociolinguistic Analysis of Sword Verses Through Muḥammad Izzat Darwazah On Al-Tafsīr Al-Ḥadīth Tartīb Al-Suwar Ḥasb Al-Nuzūl
}

\author{
Ahmad Fawaid ${ }^{1}$, Thoriqotul Faizah ${ }^{2}$ \\ Universitas Nurul Jadid, Paiton Probolinggo, Indonesia \\ ${ }^{1}$ ahmadfawaidfuady@gmail.com, ${ }^{2}$ thoriq.faizah@gmail.com
}

DOI: $10.29240 /$ alquds.v5i1.2315

Submitted: 2021-01-14 | Revised: 2021-03-09| Accepted: 2021-03-25

\begin{abstract}
This study aims to discuss Muhammad Izzat Darwazah's perspective about the sword verses and the issues of its abrogation towards the peaceful verses (ayat al-silm) on al-Tafsīr al-h\}adīth Tartīb al-Suwar h\}asb al-Nuzūl. This paper focuses on the problem; how is Darwazah's perspective on the theory of abrogation, that the peaceful verses have been abrogated by the sword verses? Furthermore, how is Darwazah's perspective on the sword verses and its relation to the peaceful verses from a sociolinguistic perspective? Using a literary research method and a sociolinguistic approach, this article concludes that, according to Darwazah, there is no abrogation of peaceful verses by the sword verses. To prove his point, Darwazah presents the facts and conditions when the sword verses were revealed. This research also concludes that, through sociolinguistic analysis, wars/jihād never occurred during the prophet's time except for self-defense. Furthermore, Darwazah argues that the sword verses, which are often used by Muslim extremists to legitimize their actions, have a different context from today, when inter-religious communities live peacefully.
\end{abstract}

Keywords: Sociolinguistic, Sword Verses, al-Tafsīr al-Hadīth Tartīb al-Suwar hạasb alNuzūl.

\section{Introduction}

Some Muslim extremists suspect that the issue of violence in the name of Islam comes from the Qur'an, as well as the peace that is also contained therein. It was because God has mentioned several verses which state the commandment for the Prophet to strive against non-muslim. Furthermore, these verses, in the next stage, are termed àyät al-sayf (verses of the sword). According to Ibn Kathīr, in his book, Tafsir al-Qur'än al-'Azim, has classified four verses that containing the 
sword verses, i.e., QS. al-Tawbah: 5, 29, 73 and al-Hujurāt: 9, based on the narration from Sayyidinā 'Alī r.a. ${ }^{1}$

The understanding of the sword verses (ayät al-sayf), in the history of Quranic exegesis, was sparked debate because there were some opinions that the sword verses had abrogated (nasakh) verses containing elements of the peace agreement (àyät al-salàm / ajyàt al-silm), Allah's command to the prophet Muhammad to be patient (al-sabr), the statement that the Prophet was only a reminder, and forgave those who do not believe and avoid arguments with those who reject the existence of God (al-'afw wa al-safb! ). ${ }^{2}$

According to näsikh-mansükh studies, the verse of the sword and peace (ayät al-sayf and peace) are contradictory statements and commands. One of the verses relating to the polemic between peace and war is in QS. al-Tawbah: 73, (regarding the jibäd orders against the mushrikin and munäfiq communities) which — it is thought — cancels the QS. al-Baqarah: 256 (concerning freedom of religion). In line with the discourse of the näsikh-mansükh, the contradiction of the two verses (ayāt al-silm and ayāt sword) are interesting to be examined from the perspective of Muhammad Izzat Darwazah, one of mufassir who considers the social context of the revelation of the verse with the tartīb nuzūli writing model. How does Darwazah respond to the verses that abrogate and are abrogated? Does he agree with the idea that a few verses of the sword abrogate peaceful verses status? Or, does he actually oppose the opinion that emphasizes abrogation of the peaceful verses?

Using a sociolinguistic approach, this article was written to answer those questions. The sociolinguistic approach supposes the text was born in a particular sociological space. In the context of this study, the abrogation of peaceful verse was placed on aspects of sociolinguistic studies with al-Tafsir al-Hadith: Tartib alSunvar hasb al-Nuzunl by Muhammad Izzat Darwazah as the object of his study. Although the research on this issue has been written by many scholars, but combining the abrogation concept with al-tafsir al-nuzüliz, which involves sociolinguistic aspects, is a new study. For example, Wardani's dissertation research at IAIN Sunan Ampel Surabaya Graduate School, which was recorded under the title Ayat Pedang Versus Ayat Damai, has elaborated in-depth the interpretation of sword verses against peaceful verses. ${ }^{3}$ Besides Wardani, Mahfuh Halimi has also written with the theme Abrogation and the Verse of the Sword:

${ }^{1}$ Ibn Kathīr, Tafsìr Al-Qur'ān Al-Az\}ìm (Beirūt: Dār al-Kutub al-'Ilmiyyah, 2017), Jilid II., 308. The term appears based on sayyidina ali ra's statement. As narrated by Sufyan ibn 'Uyaynah: "The Prophet was sent with 4 swords".

${ }^{2}$ Wardani, Ayat Pedang Versus Ayat Damai: Menafsir Ulang Teori Naskh Dalam Al-Qur`an (Jakarta: Badan Diklat dan Litbang Agama Kementerian Agama, 2011), 191.

${ }^{3}$ Ibid., 03-07 
Countering Extremists' Justification for Violence. ${ }^{4}$ Other articles that have discussed abrogation concept and sword verses are Ahmad Fawaid's dissertation with the title Kontra Narasi Ekstremisme Terhadap Tafsir Ayat-Ayat Qitäl dalam tafsìr al-Jalālayn Karya Jaläl al-dìn al-mahallì dan Jaläl al-Din al-Suyütī, ${ }^{5}$ Safrodin's article with the title Diskursus Naskh Ayat-Ayat Toleransi Oleh Ayat-ayat perang dalam alQur'an, ${ }^{6}$ and Ulya Fikriyati' dissertation, Interpretasi Ayat-Ayat "Pseudo Kekerasan"(Analisis Psikoterapis atas Karya-Karya Tafsir Hannān Laḥhām. ${ }^{7}$ As regards the previously mentioned article, I emphasize and guarantee that the entire article does not discuss the nuzuli analysis of abrogation verses.

As a beginning description, the novelty of this study is not only in the approach used for but also on the object of study, that is an idea of Darwazah as stated in al-Tafsir al-Hadith Tartib al-Suwar hasb al-Nu₹ül which places the verses of the Qur'an in a prophetic social space, with an arrangement model of the descent of the Qur'an (al-tartib al-nuгüli). Through this interpretation model, the interpreter does not become passive as a "translator" of God's words apart from the spirit of prophetic preaching, but he/she becomes active as an interpreter who considers the spirit of prophetic preaching in the present context.

This study also aims to counter-narratives of the idea of jihād, which has recently become polemic, such as the call (adhän) to jihād, which was carried out by Muslim extremist groups on the change of the text of the call to prayer bayya 'alà al-saläh to hayya' alā al-jibäd. Therefore, the contextualization of Darwazah's interpretation is also expected to be able to provide "fresh air" in the implementation of these verses as closely as possible to the context desired by the Qur'an, so that there are no more parties who misinterpret the verses of the sword as an absolute obligation in jihād.

\section{Sword Verses as a Claim of Violence in the Qur'an}

In the study of the Qur'an, many scholars have shown that the Qur'an is a tolerant book and condemns all forms of terrorism. For example, as Imam

${ }^{4}$ Mahfuh Halimi, "Abrogation and the Verse of the Sword: Countering Extremists' Justification for Violence," Counter Terrorist Trends and Analyses Volume 9 (2017): 27-35.

${ }^{5}$ Ahmad Fawaid, "Kontra Narasi Ekstremisme Terhadap Tafsir Ayat- Al- Dīn Al -Ma Ḥallī Dan Jalāl Al- Dīn Al - Suyūṭị," 2019, 299, http://digilib.uinsby.ac.id/35892/2/Ahmad Fawaid_F53314039.pdf.

${ }^{6}$ Safrodin Safrodin, "Diskursus Naskh Ayat-Ayat Toleransi Oleh Ayat-Ayat Perang Dalam Al-Qur'an,” Jurnal THEOLOGLA 30, no. 1 (2019): 51-74, https://doi.org/10.21580/teo.2019.30.1.3206.

${ }^{7}$ U Fikriyati, “Interpretasi Ayat-Ayat 'Pseudo Kekerasan': Analisis Psikoterapis Atas Karya-Karya Tafsir Ḥannān Laḥhām,” 2018, http:// digilib.uinsby.ac.id/id/eprint/25789. 
Taufiq in his book emphasizes that "al-Qur'an is not a book of terror, this is shown by a number of verses of peace that are more numerous than verses of war." ${ }^{8}$ M.A.S Abdel Haleem describes in detail the terms jihād and qitāl. According to him, the two terms of the polemic cannot be understood from a linguistic aspect alone but must also involve the historical element behind it to get a complete understanding. ${ }^{9}$ In a historical context, Ahmed Al-Dawoody mentions that jihād and qitāl are casus belli, namely conditions in which Muslims are required to fight, ${ }^{10}$ or as Zaki Ibrahim's opinion, he mentions the qitāl theory in Islam as a "temporary strategy" (interim strategy) because there are certain reasons. ${ }^{11}$

Although scholars have demonstrated a tolerant aspect of the Qur'an and corrected misperceptions of jihad and qitāl, violence in the name of the Qur'an finds legitimacy when confronted with the concept of nasakh-mansükh. ${ }^{12}$ When extremist Muslims use this concept, they argue that the verses jihād and qitāl have abrogated more than a hundred verses on peace, coexistence, patience, tolerance, and Muslim and non-Muslim relations. ${ }^{13}$ To support his argument, extremist Muslims cite a number of classical literature, one of which is the arguments of Jalāl al-Dīn al-Suyūtī (d. 911 H.), ${ }^{14}$ Ibn Kathīr (d. 774 H.), ${ }^{15}$ and Muhammad Baqir al-Majlisi (d. 430 H.). ${ }^{16}$

Genealogically, the idea of the abrogation of peaceful verses by sword verses emerged in the 2nd century A.D. ${ }^{17}$ Qatādah (d. $\left.117 \mathrm{H}\right)$, gives an indication of QS. Al-'Ankabūt: 46, on the prohibition of debate with the wrongdoers of the People of the Book, by surah al-Tawbah. ${ }^{18}$ According to Qatādah, war orders are a more effective way to deal with them. In this case, Abū 'Ubayd al-Qāsim bin

${ }^{8}$ Imam Taufiq, Al-Qur'an Bukan Kitab Teror (Yogyakarta: Bentang Pustaka, 2015).

${ }^{9}$ M.A.S. Abdel Haleem, "Qur'anic 'Jihād': A Linguistic and Contextual Analysis," Journal of Qur'anic Studies 12 (2010): 147-66, https://doi.org/10.3366/e1465359110000999.

${ }^{10}$ Ahmed Mohsen Al-Dawoody, "War in Islamic Law: Justifications and Regulations" (University of Birmingham, 2009),101.

${ }^{11}$ Zakyi Ibrahim, "A Sociopolitical Analysis of the Verses of Peace: Qur'an 8:61-62," International Journal on World Peace 30, no. 1 (2013): 89.

12 Jeffry R Halverson, R Bennett Furlow, and Steven R Corman, "How Islamist Extremists Quote the Qur'an," Arizona State University Center for Strategic Communication, 2012.

${ }^{13}$ Halimi, “Abrogation and the Verse of the Sword: Countering Extremists' Justification for Violence."

${ }^{14}$ Jalāl al-Dīn Al-Suyūtī, Al-Itqān Fì 'Ulūm Al-Qur'Ān (Beirūt: Dār al-Fikr, t.th.), II., 24.

${ }^{15}$ Ibnu Kathir, Tafsìr al-Qur'ān al-Až̀m (Beirūt: Dār al-Kutub al-'Ilmiyyah, 2017), II., 308.

${ }^{16}$ Muhammad Bāqir Al-Majlisī, Bỉār Al-Anwār Al-Kāmi’ab Li Al-Durar Akbbār AlAìimmah Al-Athār (Beirūt: Mu'assasat al-Wafā', 1983), IXVII., 53.

17 In relation to the discussion of the genealogy of "sword verse" and its implications for the study of mansūkh abrogation, Wardani has explained in detail in his dissertation published by the Ministry of Religious Affairs. In this section, this article refers to the academic work. See Wardani, Ayat Pedang Versus Ayat Damai: Menafsir Ulang Teori Naskh Dalam Al-Qur'an.

18 Qatādah bin Dỉ'āmah Al-Sadūsī, "Kitāb Al-Nāsikh Wa Al-Mansūkh Fī Kitāb Allāh Ta'ālā," dalam Silsilat Kutub Al-Nāsikh Wa Al-Mansūkeh (Beirūt: Mu'assasat al-Risālah, 1998), 22. 
Salām (d. $224 \mathrm{H}$ ) argued that at least QS. Al-Tawbah: 5 and 9 have abrogated nine verses, namely; QS. Al-Ghāshiyyah: 22., QS. Qāf: 45., QS. Al-Māidah: 2., 13., QS. Al-Jāthiyyah: 14., QS. Muḥammad: 4., QS. Al-Anfāl: 61., QS. al-Nisā’: 90., and QS. al-Mumtahanah: $8{ }^{19}$

Furthermore, in the 4th century A.D., the legitimacy of the abrogation of the peaceful verses 'gave birth' to the term "sword-verse", which is based on the history of 'Alī bin Abī Tālib. ${ }^{20}$ When Ibn 'Abbās asked 'Alī Ibn Abī Tālib about the lack of basmalah at the beginning of Surah al-Tawbah, he replied that in basmalah contained the meaning of safe, while Surah al-Tawbah came down with a sword. ${ }^{21}$ The idea of " sword-verse" strengthened in the hands of Hibatullah ibn Salamah (d. $410 \mathrm{H})$. In his academic work, Hibatullah classifies a number of verses that are considered to annul and be annuled. He refers to the term sword verses abrogate some tolerance verses. ${ }^{22}$ It was from Hibatullah that the use of the term "sword verse" became popular among later scholars, such as al-Baghdādī (d. 429 H), Makkī al-Qaysī (d. $437 \mathrm{H}$ ) and Ibn al-'Arabī (d. 543 H). ${ }^{23}$

The discourse of sword verses from then to now has become not only a polemic issue among scholars but also justification for extremist Muslims. When the ISIS group occupied Sinjar, Iraq, or so-called Ninnawā territory in 2014, they justified its actions against Yazidi members using sword verses. ${ }^{24}$ Imam Samudra, the perpetrator of the Bali Bombings, 2002, as Wardani wrote, used a sword verse quoted from Tafsīr Ibn Kathīr to justify the actions of the Bali Bombings. Recently, although not clearly stated, some extremist groups uploaded propaganda videos on social media calling for azan hayya 'alà al-jïhäd-a successor to hayya 'alà al-salāh__and praying with swords. ${ }^{25}$

${ }^{19}$ Abū 'Ubayd, Kitāb Al-Nāsikh Wa Al-Mansūkh (Beirūt: Dār al-Kutub al-'Ilmiyah, 2006), 67-68.

20 'Alī ibn Abī Tālib said: "The Prophet (peace and blessings of Allaah be upon him) was sent with four swords; One sword was addressed to the Arab pagans. Allah ta'âlā said: Kill the polytheists wherever you find (QS. al-Tawbah: 5)." Ibn Abī Hātim, Tafsìr Al-Qur'ān Al-'Až̀im, Musnadan 'an Al-Rasūl Sallā Alläh 'Alayh Wa Sallam Wa Al-Sabābah Wa Al-Täbi'in, ed. As'ad Muhammad Al-Tayyib (Riyād: Maktabat Nizār Mustafā al-Bāz, 1997), 1753

${ }^{21}$ Jalāl al-Dīn Al-Suyūtī, Al-Durr Al-Manthūr Fì Al-Tafsìr Bi Al-Ma’thür (Kairo: Markaz Hajr li al-Buhūth wa al-Dirāsāt al-'Arabiyyah wa al-Islāmiyyah, 2003), Juz, VII., 227.

${ }^{22}$ Hibah Allah Al-Salamah, Al-Näsikh Wa Al-Mansükeh (Kairo: Maktabat al-Mutanabbi, t.th.), 347 .

${ }^{23}$ Wardani, Ayat Pedang Versus Ayat Damai: Menafsir Ulang Teori Naskh Dalam Al-Qur`an, 407. for Violence."

${ }^{24}$ Halimi, "Abrogation and the Verse of the Sword: Countering Extremists' Justification

${ }^{25}$ Andita Rahma, "Polisi Tangkap Pelantun Azan Hayya Alal Jihad," TEMPO.CO, December 4, 2020. 
As a beginning description, in scholars' view, the verses of the sword are divided into six verses. First, QS. al-Tawbah: 5. The majority of scholars designate this verse as a sword verse, in addition to the narration referred to 'Ali, verse 5 is also included in the last verses of al-Tawbah, so it is considered as a representation of the final attitude of the Qur'an towards non-Muslims. ${ }^{26}$ As a final attitude, there must be the verses abrogated by the thid verse. According to Abu 'Ubayd, QS. alTawbah: 5 specifically cancel QS. al-Māidah: 2 and QS. Muhammad: $4 .{ }^{27}$ This verse is also considered to annul QS. al-Ghāshiyah: 22, QS. Qāf: 45, QS. alMā'idah: 13, QS. al-Jāthiyah: $14{ }^{28}$

Second, QS. al-Tawbah: 29. besides being categorized as a sword verse, this verse is known as the tax verse (āyät al-jizyah) or war verse (āyāt al-qitāl or āyāt alqatl wa al-qitād). The context of asbäb al-nuqūl is the beginning of Islamic expansion after the conquest of Mecca. At that time, Muslims began to show their glory to other groups, including the People of the Book (Ahl Kitab). It was then that concerns were raised among the Christian-Arabs who encouraged them to join the Christian-Romans to defeat the Muslims. ${ }^{29}$

As stated earlier, Ibn Kathirr stated plainly that the second verse of the sword is to fight the community of the People of the Book. Qatādah, ${ }^{30} \mathrm{Ibn}$ Taymiyyah (d. $728 \mathrm{H})^{31}$ and Muqātil bin Sulaymān (d. $150 \mathrm{H}$ ) explains that this verse abrogates the verse on the prohibition of arguing with the People of the Book except in a good way on QS. al-'Ankabūt: 6. ${ }^{32}$

Third, QS. al-Tawbah: 36. Ibn Hẹajar al-Haytāmī (d. 973 H) holds that this verse and verse 41 are part of a group of sword verses containing the absolutely of the commandment of war (fighting all polytheists indefinitely place and time). ${ }^{33}$ This verse abrogates QS. al-Baqarah: 109 on the prohibition of fighting in the Masjid al-Haram and the prohibition of fighting in Hurum (sacred) month. ${ }^{34}$

Fourth, QS. al-Tawbah: 41. Ibn Hajar argues that the most final command of jihād lies in this verse. On the other hand, Abū 'Ubayd explains that this verse 189-199.

${ }^{26}$ Wardani, Ayat Pedang Versus Ayat Damai: Menafsir Ulang Teori Naskh Dalam Al-Qur'an,

${ }^{27}$ Abū 'Ubayd, Kitäb Al-Näsikh Wa Al-Mansükh, 167

28 'Ubayd, 67-68.

${ }^{29}$ Muhammad T\}āhir Ibn Ashūr, Tafsìr Al-Tahrìr Wa Al-Tanwìr (Tunisia: Dār al-Tunisia, 1984), X., 162.

${ }^{30}$ Al-Sadūsī, Kitāb Al-Nāsikh Wa Al-Mansūkh Fī Kitāb Allāh Ta’ālā, 45.

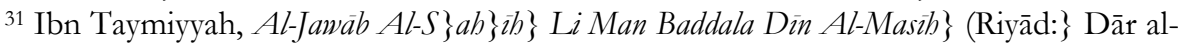
'Āsimah, 1414 H), Juz, I., 216 2003), II., 521.

${ }^{32}$ Muqātil bin Sulaymān, Tafsìr Muqātil Bin Sulaymān (Beirūt: Dār al-Kutub al-'Ilmiyyah,

${ }_{33}$ Ibn Hajar Al-Haytāmī, Tub\}fat Al-Mub\}tāj Bi Sharb Al-Minhäj (Mesir: Mat\}ba'at Must $\}$ afā Muh\}ammad, t.th.), IX., 212.

${ }^{34}$ Al-Sadūsī, Kitāb Al-Nāsikeh Wa Al-Mansūkeh Fì Kitāb Allāh Ta’àlā, 33-34 
is considered to make jihād a fard 'ayn (individual obligation). However, after going down QS. al-Tawbah: 122 concerning the responsibility of education and considered to invalidate this verse, the command changed to fard kifäyah (collective obligation). ${ }^{35}$ Fifth, QS. al-Tawbah: 73. Ibn Kathïr explains this verse as an order against hypocrites, ${ }^{36}$ although there are differences of opinion regarding the projection of this verse into reality because hypocrisy is not a physical form. ${ }^{37}$ QS. Al-Tawbah: 73 also annuls a number of verses, such as freedom of religion (QS. al-Baqarah: 256), ${ }^{38}$ prohibition on hurting hypocrites (QS. al-Ahzāb: 48), and the prohibition of fighting in the sacred month (QS. alBaqarah: 217). In fact, al-Qurtūbī states that this verse invalidates all verses relating to the commandments of the peace treaty, apologizes, and does not interfere with or allow non-Muslims. ${ }^{39}$

Sixth, QS. al-Hujurāt: 9 that commands to fight against the rebel group from Muslims. It is categorized in sword verse because these rebels are considered dangerous,${ }^{40}$ and the status to fight these kinds of people is valid. However, the rebels are not wicked people, only that they are misinterpreted. ${ }^{41}$ Therefore, there is a difference between the war against the infidels and the bughäh, which is, in fact, the fellow Muslims themselves i.e., the captive party should not be executed or made slaves. Children and women should also not be killed or detained. Their wealth also does not fall into the category of ghanimah (spoils of war). In fact, the captive men must be released when the situation is deemed safe.

\section{Izzat Darwazah and the Nuzūlī Tafsir Model: Intellectual Travel}

One of the monumental works in the field of nuzūli exegesis is Kitäb alTafsir al-Hadith Tartib al-Sunvar Hasb al-Nurül which is the focus of discussion in this research, written by Muhammad Izzat Darwazah, an Arab political fighter who was involved in the movement against the people. Zionists. His full name is Muhammad Izzat bin 'Abd al-Hādi bin Darwīs bin Ibrāhīm bin Hasan Darwazah.

35 Abū 'Ubayd, Kitäb Al-Nāsikeh Wa Al-Mansūkeh, 164

${ }^{36}$ Ibn Kathīr, Tafsìr Al-Qur'ān Al-Ažìm (Beirūt: Dār al-Kutub al-'Ilmiyyah, 2017), vol. 2, $220-224$

${ }^{37}$ Wardani, Ayat Pedang Versus Ayat Damai: Menafsir Ulang Teori Naskh Dalam Al-Qur`an.,

${ }^{38}$ Ibn Al-Jawzī, Nawāsikh Al-Qur'ān (Beirūt: Dar al-Kutub al-'Ilmiyyah, t.th.), 94.

39 Abū Bakr Al-Qurtubī, Al-Jāmi' Li Abkàm Al-Qur'ān (Riyāọ: Dār 'Alam al-Kutub, 2003), XIII., 205.

${ }^{40}$ Wardani, Ayat Pedang Versus Ayat Damai: Menafsir Ulang Teori Naskh Dalam Al-Qur an, 194.

${ }^{41}$ Wardani, 226. 
He was born at the end of June 1887 or to coincide with 11 Shawwal $1305 \mathrm{H}$ in Nablūs City, Palestine. According to his grandfather, he came from an Arabic family with the name of the Farihăt tribe, while Darwazah was a nickname for his family and ancestors who worked as tailors (darrāz). In fact, his father and grandfather still continued the tradition by trading cloth at Nablūs ${ }^{42}$

His formal education began in 1895 in a public elementary school which continued at the secondary level of Madrasah al-Rashīdiyyah and was completed in $1905 \mathrm{AD}^{43}$ Then, unable to continue to a higher level, he studied books from various fields independently, such as language, literature, poetry, history, social, philosophy, interpretation, hadith, jurisprudation, and kalam. Some of these books are in Turkish as well as translations from foreign languages that he obtained from various places. In addition to books, He also reads foreign articles, such as India, Palestine, Syria, Iraq, and others. ${ }^{44}$ However, among these areas, there are two scientific disciplines that become the main tendencies, namely history and interpretation. This is evident with most of his works discussing interpretation and intertwining with history.

Darwazah mentions in his book that the journey of life after the span of $1905 \mathrm{AD}$ is divided into three times. The first period was when He worked as an office employee, such as head of Uthmani post office in Beirut, Secretary in Diwann al-Amir 'Abd Alläh (1920), principal (1922-1927), head of waqf agency (19271932), and other staffing jobs. ${ }^{45}$ The second period is termed majra al-siyasi (political school). Darwazah served as branch secretary at Hizb al-I'tiläf (1909), secretary at Jam'iyyah al-'Imizyah al-'Arabiyyah in Nablūs (1911), secretary of the Arab-Palestinian Muktamar in al-Quds (1919), and other positions related to administration and politics. ${ }^{46}$ The third period is called al-nasyat al-ilmì (scientific activity). His extensive and varied experience as a politician led him to become an Arab nationalist. As a movement activist, Darwazah read articles by Abduh, Rāshid Rị̣ā, Mustafā Șādiq al-Rāfi'ī, and Qāsim Āmīn. ${ }^{47}$ He actively fought for the rights of Palestinians from the British colonies, until at a time when political conditions were raging at the time, he was a prisoner of prison in Damascus (1936-1940). This made the journey of his movements choked. However, on the other hand, Darwazah managed to memorize the Qur'an and spawn the main works related to the Qur'an, such as 'Asr al-Nabi' 'alayh al-Salam wa Bi'atih qabl al-

42 Muhammad Izzat Darwazah, Al-Tafsì Al-Hadith Tartīb Al-Suwar Hasb Al-Nuzül (Beirūt: Dār al-Gharb al-Islamī, 2000), X. 23.

${ }^{43}$ Darwazah, 23.

${ }^{44}$ Darwazah, 26.

${ }^{45}$ Darwazah, 26.

${ }^{46}$ Darwazah, 26.

${ }^{47}$ Rudy al Hana, "Konsep Kafir Perspektif Izzat Darwazah Dan Implikasinya Pada Realitas Kekinian,” ISLAMICA: Jurnal Studi Keislaman 14, no. 2 (2020): 171-93. 
Bi'thah min al-Qur'än, Sirah al-Rasül 'alayh al-Saläm min al-Qur'än, and al-Dustür alQur'āni fi Shu'ūn al-Hayāh. ${ }^{48}$

It should be noted that these three times are not separate, but occur simultaneously from different sides, such as the time when $\mathrm{He}$ served as headmaster in al-Najäh al-Watäniyyah al-Ibtidä'iyyah wa al-Thanāwiyyah in 1922-1927, He was also secretary at Jam'iyyah al-'Imiyyah al-Arabiyyah. In 1948, Darwazah suffered from an illness that caused his physical abilities to decline and was unable to continue his movements. Since then, the flow of his political life has stalled, replaced by scientific activities through the media of writing.

Darwazah's life journey ended at the age of 96, precisely in 1984 A.D. $1401 \mathrm{H}$ in Damascus leaving behind one son and three daughters, namely Zuhair, Salmā, Najāḥ, and Rudaynah from his first wife named Fātimah bint Qāsim Darwazah (d. $1359 \mathrm{H})$. As for his second wife, Lā’iqah bint Anīs al-Tamīmī (d. $1396 \mathrm{H}$ ), he had no children. It is described that Darwazah is a figure with strong faith, religious principles, homeland, and humanity. He never clashed, hurt, and was hypocritical. Also, his life was also full of simplicity and avoided greed for wealth. ${ }^{49}$

The reason why darwazah wrote commentaries was because he saw the number of "blind taklīd" and the meaningless reading of the Qur'an, thus causing youth in his day to turn away from reading that educated their minds and morals. So, the presence of this work is expected to be a means of reviving their motivation for life based on the al-Qur'an, al-Sunnah, and the principles of the Prophet's life during the world. ${ }^{50}$

\section{Nuzūlī Exegesis Model as Approach}

Before determining the tartï nuqūi method, Darwazah examined several scholars who applied similar methods. The first scholar to apply this method in his mushaf was 'Alī bin Abī Tạalib, and no one has yet disavowed this method. The sequence of his mushaf begins from Surah al-'Alaq, al-Muddaththir, Nūn, alMuzzammil, and so on until the end of the Surah Makkiyyah and Madaniyyah. ${ }^{51}$ Furthermore, there is Sayyid Qutb (d. $1383 \mathrm{H}$ ) with his thematic commentary, Mashähid al-Qiyamah fi al-Qur'an which, as the title of his work, examines only the doomsday term in the Qur'an. It was followed later by Darwazah with a complete interpretation in 30 juz in al-Tafsir al-Hadith Tartïb al-Suwar hasb al-Nuzuñl. Although

\footnotetext{
${ }^{48}$ Darwazah, Al-Tafsir Al-Hadith Tartìb Al-Suwar Hasb Al-Nuzül, IX., 26.

${ }^{49}$ Darwazah, IX., 32.

${ }^{50}$ Darwazah, 5.

${ }^{51}$ Al-Suyūtī, Al-Itqān Fì 'Ulùm al-Qư'ān, 65.
} 
not widely studied, the work occupies a position as the originator of chronological interpretation that elaborates the sequence and context of a verse comprehensively before other interpretations appear in the same method, such as Ma 'ärij al-Tafakekur wa Daqä’iq al-Tadabbur: Tafsì Tadabburi li al-Qur'ān al-Karim bi hasb al-Tartīb al-Nũūl by 'Abd al-Rahmān Hasan Hanbakah al-Maydānī (d. 1425 H), Absan al- Qasas: Tärikh al-Qur'ān kamä Warada min al-Mashdar ma'a Tartib alSunvar hasb Nu₹ūl which is a chronological commentary by Ibn Qarnās, and Fabm al-Qur'ān al-Hakim: al-Tafsìr al-Wädih hasb Tartīb al-Nu乏ülby 'Abīd al-Jābirī (d. 1431 $\mathrm{H})$ who also applied the tartib nuश्üli method. In contrast to some of these interpretations, al-Tafsir al-Hadith is not too involved in the technical discourse of the Makkiyyah-Madaniyyah, but rather on the condition and events of the revelation of a verse. ${ }^{52}$

In addition to the Muslim commentator, there was an orientalist who participated in studying the Qur'an according to tartîb nuzūlī, namely Theodore Noldeke. His work was translated into Arabic under the title Tärikh al-Qur'ān. However, the book is not considered a commentary because He positioned the Qur'an as the order of the text alone, not as a holy book. It is also noted that the Indonesian scholars who initiated the application of this method Muhammad Quraysh Shihab with his work al-Mișbäh..$^{53}$ However, the broad reference in this method is still Izzat Darwazah because the interpretation is considered more complete. It is said that one of Darwazah's benchmarks in determining tartïb nuzülì was Qudūr Ugli because the preparation of the chronological order was under the supervision of the Egyptian Interior Ministry's scientific experts and had been mutually agreed upon. ${ }^{54}$

Darwazah's research in its application to this method is the influence of the disciplines involved. However, although his work is dominated by historicalthemed books, He still makes the Qur'an the primary source, whereas history as a secondary source. However, it is undeniable that his interpretation was also influenced by the political ideology pursued during his lifetime. This can be proven by Darwazah's other works that are themed on jihād and life issues. ${ }^{55}$

In al-Tafsir al-Hadith, Darwazah begins his interpretation with surah alFatihah and ends with surah al-Nasr. He balances the source of this commentary from the narration of the Prophet (peace and blessings of Allah be upon him) and

\footnotetext{
${ }^{52}$ Aksin Wijaya, Sejarah Kenabian Dalam Perspektif Tafsir Nuquli Muhammad Izzat Darwazah (Bandung: Mizan, 2016). 79.

${ }^{53}$ Wijaya, 80.

${ }^{54}$ Darwazah, Al-Tafsìr Al-Hadith Tartïb Al-Suwar Hasb Al-Nuzül, I., 12.

55 Tazul Islam, "Christian-Muslim Relations: An Analysis of the Quranic Articulation of Christian Friendliness to Muslims," Al-Bayan: Journal of Qur'an and Hadith Studies 17 (2019): 24-37, https://doi.org/10.1163/22321969-12340068.
} 
tabiin, and he explains his verses from the results of ijtihad and his analysis based on the scientific field and purpose of writing this book. ${ }^{56}$ The method Darwazah uses in the preparation of his commentary is the tablili (analytical) method. It is judged so because He explains the verses in detail and in-depth on the aspects interpreted, such as asbäb al-nuzūl and the vocabulary of the Perspective of Arabic linguistics. He also quoted other verses that have munäsabah with the verses being discussed, including badith prophet, qawl companions, tabiin, and previous commentator opinions that are considered relevant. ${ }^{57}$ More than that, Darwazah also grouped the verses according to the theme of the discussion.

The model of this book interpretation is known as adabi-ijtima't (community-culture). ${ }^{58} \mathrm{It}$ is evident in his commentary that Darwazah focused on the accuracy of the editor and connected the context of the verses' revelation at the time of the Prophet with the law or events at the time He wrote the commentary. He revealed that the link between the Qur'an and the sirah nabawiyyah is an inseparable unity. This is because the Qur'an reflects the life journey of the Prophet (peace and blessings of Allah be upon him) with friends in the course of da'wah and the development of Islam. Thus, related to the sword verses, the Qur'an becomes a clue and a description of the Prophet's attitude towards the Muslim community who rebelled, the People of the Book, nonMuslims, and hypocrites. ${ }^{59}$

When observed carefully, the method of interpretation with Darwazah's al-tafsir al-nuгüli approach has a distinctive character, i.e. a) the classification of verses based on the same theme, b) explaining foreign and musykil words, in a nutshell, c) explaining the sentences used as objects of interpretation globally, d) explaining the correlation of verses to know asbäb al-nuzül, e) gathering the context of verses based on the law, principles, to implied messages contained in them, $f$ ) bring up the sirah nabawiyyah in order to complete the understanding of a verse or topic, g) affirm the position of a word or sentence in the linguistic structure, $h$ ) pay attention to the verse or surah concerns with the relevant verse in order to affirm the reasonable truth, i) help lafaz and the composition of the Qur'an in

56 'Abd al-Fattah Al-Khalidi, Ta'rîf Al-Dārisin Bi Manāhij Al-Mufassirin (Damaskus: Dār al-Qalam, 2002), 301-302.

${ }^{57}$ Ahmad Fawaid and Nafi'ah Mardlatillah, "Bias Ideologis Tafsir Hizb Al-Tahrīr," MAGHZA: Jurnal Ilmu Al-Qur'an Dan Tafsir 5, no. 2 (2020): 184-209, https://doi.org/10.24090/maghza.v5i2.4243. Hati, 2006), 25.

${ }^{58}$ M Quraish Shihab, Rasionalitas Al-Qur'an: Studi Kritis Atas Tafsir Al-Manar (Lentera

${ }^{59}$ Darwazah, Al-Tafsìr Al-Hadìth Tartïb Al-Suwar Hasb Al-Nuzūl, I., 143. 
obtaining the intended meaning, j) use a language style that is close and easy and avoid unpopular language styles, and $\mathrm{k}$ ) repeat or extend the interpretation. ${ }^{60}$

\section{Izzat Darwazah and The Counter Narrative of Sword Verses:}

\section{Sword Verses Through Darwazah's Perspective}

The opinion that a large number of verses of peace have been abrogated by the verse of the sword is a problem for Muslims because as a guide until the end of time, the Qur'an should contain teachings that can make religious people harmonious and tolerant. As a preliminary view, Darwazah does not deny opinions regarding the mention of some verses with ayat al-sayf. When interpreting al-Tawbah: 5, he has mentioned that some abl al-ta'wnl wa al-mufassirum indeed consider the verse to absolutely abrogate peaceful verses, some consider the effectiveness of this verse only until an agreed time, and others also consider there is no exception whatsoever after the revelation of this verse. However, Darwazah asserts that these opinions are ghuluw (beyond) and munaqadah (contrary) to the provisions of the Qur'an against the law of the muhkam in the form of no war except against the enemy, and let the submissive and merciful and live in harmony and do justice to them. ${ }^{61}$

Regarding the sword verses, Darwazah quotes the narration mentioned by Ibn Kathir in his commentary, QS. al-Tawbah: 5, 29 and 73 and al-Hujurāt: 9. Furthermore, he says,

“... surprisingly, al-Tabārī argues that this verse includes those who make a covenant at the end of the covenant period, those who break the covenant and those who do not make any covenant without separation whereas Allah has established in QS. al-Mumtahanah: 8 the ability to do good and justice to those who do not fight and expel Muslims, and the verse is muhkam. That is, Allah does not forbid to make peace with those who do not confront the Muslim community of any religion they come from (min ayyi millah kānu), even if some of them do not do any (peace) agreement!."62

The explanation of al-Tabāri and the verse is clear in terms of its purpose and context, namely fighting the pagan community who made the covenant and violated it. This explanation justifies the assumption that this verse is a sword verse, while the absolute conduct of the war against all pagans is advice only and is not the purpose or context of this verse. Thus, the commandment contained in this verse has been to overturn the provisions of the Qur'an, which are gathered in a large number of verses based on the principles of muhkam such as the absence

\footnotetext{
${ }^{60}$ Darwazah, I., 69.

${ }^{61}$ Darwazah, IX., 351.

${ }^{62}$ Darwazah, IX., 352.
} 
of compulsion in religion, the call to Islam with good wisdom and advice, and the debate with better, encouragement of good and justice against those who do not fight the Muslims and drive out of their countries." ${ }^{93}$

The presumption that the verse talhamu (swallow at once) a number of verses relating to no compulsion in religion, there is no prohibition to do good to non-Muslims who do not show hostility, and that the command of war only applies to non-Muslims who fight Muslims and exceed the limits, should be reviewed by looking again sirah nabawiyyah and who only fight enemies who exceed the limits and break the covenant.

Regarding the hadith of the Prophet narrated by Abu Hurairah: "I have been commanded to fight against a group of people, until they say là iläh illa Alläh. Whoever says it, then his property and soul are protected from me, except his rights and reckoning to God." (HR. Abu Hurairah) ${ }^{64}$ Darwazah shows that there is no contradiction between the hadith and the content of QS. Al-Tawbah: 5 and its munāsabah with Surah al-Muzzammil and al-Kāfirūn as well as those that Darwazah has explained at length in the interpretation of the two surahs. ${ }^{65}$

More specifically than QS. al-Tawbah: 5, is enshrined in the order of the sword addressed to the People of the Book in verse 29. al-Tabāri mentions that this verse came down concerning the concerns of Muslims when the musbrikum forbade them to enter Mecca. Then, Allah sent down this verse with the command of the Tābūk War, which was intended to take the jisyah (tax) on the rights that had been destroyed from the Muslims. Therefore, this verse is also known as ajyat al-jizyah because before the revelation of this verse, and the Prophet had never collected taxes. ${ }^{66}$

Darwazah concluded that this verse shows the command of the Muslims to fight all the People of the Book absolutely. The people of the Book are those who have not forbidden the affairs which Allah has forbidden and are not religious in the right way. However, Darwazah believes from the munasabah side that the opinion is contrary to the general principle of muhkam which he has described in QS. al-Nisā': 90-91 and QS. al- Mumtasanah: 8-9 about the ability to do good to the people who do not fight the Muslims and not expel the Muslim community from his country. ${ }^{67}$

\footnotetext{
${ }^{63}$ Darwazah, IX., 356.

${ }^{64}$ Darwazah, IX., 357.

${ }^{65}$ Darwazah, IX., 358.

${ }^{66}$ Darwazah, IX., 399.

${ }^{67}$ Darwazah, IX., 403.
} 
Darwazah's perspective of the qitāl verses was not much different from that of Jamāl al-Bannā. In his famous book, Jihäd, Jamāl wrote a special chapter on the Qitäl verse. As a gateway to understanding the qitāl verse, Jamāl discussed the prophet's migration from Mecca to Medina which had implications for the prophet's da'wah model. Hijrah was not only the movement of Muslims to Medina because of the pressure of the Quraish people, but more than that it was an order from Allah to the prophet to implement Islam as a strong system of government. In Medina, the Prophet instilled a spirit of brotherhood in the form of the ummah and maintained the unity of the ummah. Under these conditions, according to Jamal, Islam allowed the prophet to fight against enemies who were trying to destroy the brotherhood and unity of the country as contained in QS. Al-Hajj: 39-40.

In the context of the previous verse, QS. al-Hajj: 39-40, both Darwazah and Jamal al-Banna, argues that the teachings of war in Islam serve as a defense against enemies who try to persecute Muslims. However, the two of them differ in their attitude towards the two verses. Darwazah, in his Tafsir, tries to stem the assumption that Islam was founded by the sword and that the verse of peace has been abolished by the verse of the sword. Meanwhile, Jamal wanted to emphasize that Islam as a Revolutionary Religion is different from the previous teachings and tolerant towards people of other religions as long as not persecuted. ${ }^{68}$

\section{Contextualization of Sword Verses in Peaceful Discourse}

Some of Darwazah's exegesis of sword verses are not much different from each other. He considers that the verses of the sword do not abrogate all the verses of peace in the Qur'an. Besides, from these conclusions, Darwazah's thought flow from sociolinguistic paradigm to produce such thinking can also be studied.

According to Fathur Rokhman, quoting from Bram \& Dickey, sociolinguistics is a study that focuses on how language functions in society. This study also tries to explain how an individual is able to use language rules appropriately in a variety of conditions. Individual involvement is also included in this study because it has a role and function as a social being. Thus, social linguistic studies have a share in the influence of a community on language and vice versa as reciprocity of social elements. ${ }^{69}$

From this explanation, it can be concluded that there are four forming elements in sociolinguistic studies, namely social conditions or conditions, the speaker's social identity, the identity of the object or target, and the language or

$\mathrm{pdf} /$.

${ }^{68} \mathrm{Jamal}$ Al-Banna, Jihad (t.tp: t.p, n.d.), https://kutub.freesite.host/tag/ جمال_البنا-جهاد

${ }^{69}$ Fathur Rokhman, Sosiolinguistik: Suatu Pendekatan Pembelajaran Bahasa Dalam Masyarakat Multikultural (Graha Ilmu, 2013), 2. 
dialect used. Similarly, the study in al-Tafsir al-hadith—which in addition to historical, Darwazah's use of tartib nuzunti certainly has a close association with linguistic studies and contextualization of social conditions when the sword and peaceful verses were passed down to present conditions. In his commentary, he stated, "Thus (tartib nuzül), the collection of the breadth of the revelation of the Qur'an, the breadth of conditions, correlations, limits, and understanding in the Qur'an can be revealed clearly the wisdom of the revelation (verse or surah)." ${ }^{, 70}$

Not only that, by mentioning the events behind the revelation of a surah, Darwazah intends to present contextual honesty behind the text of the Qur'an so that generations who live long after the death of the Prophet (peace and blessings of Allah be upon him) retrace traces of his story because the fact that the Qur'an is not a text born of empty space. This, whether realized or not, is really necessary in understanding a text comprehensively today so that readers and practitioners of the Qur'an avoid misrepresentation, as has been the case lately.

From a sociolinguistic approach, Darwazah's interpretation of the verses of the sword, which he considered to have no implications or the interpretation of peaceful verses, can be seen from social conditions when he interprets verses of the Qur'an during his life. As an activist and scholar, he does not rule out the interpretation of the Qur'an, especially with regard to the position of a verse or surah when the messages in it are conveyed to the Prophet ( peace and blessings of Allah be upon him). As explained about the verse of the sword in QS. alTawbah: 5 which is considered to be the most peaceful verses, Darwazah reveals that the opinion is too far from the context of the true verse.

Dealing with the interpretation of peaceful verses, it appears that Darwazah does not think at all that the verses are losing relevance even since the period of Prophet. As for example when he interprets a verse that speaks of religious freedom, namely al-Baqarah: 256 . This verse, which advocates a ban on compulsion in religion, is based on the case of a man from the Ansar who forced his black slaves to Islam. When the matter reached the Prophet, then Allah revealed this verse. In another narration, it is narrated that some women from the Ansar vowed that when they bear a son, they will be Jews or Christians, hoping for a long life for them. Then, with age, they forced the child to convert to Islam. The foregoing revealed this verse. However, Darwazah said that the histories do not come from the book of hadith mu'tabarah. ${ }^{71}$

There are some opinions narrated by the commentator about the limits of the validity of this verse that it applies specifically to the People of the Book and other than the Arabs, that if they are willing to pay jiryah, then Muslims are prohibited from forcing them to convert to Islam. Furthermore, as for the

\footnotetext{
${ }^{70}$ Darwazah, Al-Tafsì Al-Hadith Tartïb Al-Suwar Hasb Al-Nuzūl, IX., 9.

${ }^{71}$ Darwazah, VI., 471.
} 
Polytheists, they will have no choice but to Islam or be slain. Heeding this opinion, it can be concluded that this verse was revealed before the legality of war, so there is no way other than coercion because this verse is considered to be annuled. However, the Qur'an gives the legality of taking taxes from the people of the Book only. ${ }^{72}$

However, Darwazah argues that the opinions on this verse are not in valid (sahih) books. He also relates this verse to the interpretation in QS. al-Kāfirūn on the freedom of Islam. Darwazah came to the understanding that the principle of the application of Surah al-Kāfirūn and this verse is amr muhkam ghairu mansükh (the affair of the muhkam that is not removed). Furthermore, the war against nonMuslims (ghairu al-Muslimin) applies only to those who are hostile and transgressive, whereas if the non-Muslims are not hostile to Islam or do sulh (peace) by paying taxes, or even if they do not pay taxes, they maintain the benefit of the Muslims, and then the community-without exception between the people of the Book, the Arabs, non-Arabs or the pagans—should not be fought. ${ }^{73}$

Therefore, in contrast to the commentator opinions mentioned in the initial chapter that only look at the structural approach of language, Darwazah tries to fulfill the function of language as a means of interaction that can influence the target (khitäb). He not only viewed a statement in the Qur'an as rigid, but rather collaborated the meaning that existed with the condition of the society that accepted it. Furthermore, Darwazah explains in QS. al-Mā’idah: 13 Concerning those who break the covenant that reads, "(But) because they broke their promise, I cursed them, and We made their hearts petrified. They change the words from their places and have forgotten a portion of what they were reminded of. and you (Muhammad) will never see treachery from them except a few of them, hence forgive them and let them, indeed, Allah loves those who do good."

These verses contain a reminder of the events of Bani Israel and The Christians when God holds an agreement with them to be consistent on the right path, carry out the obligations, and confirm the messengers who came by His guidance. But Allah cursed them and hardened their hearts for their violation. Then came the verse after him (al-Mā'idah verse 13) which contained the opposite verse 12, the call of the Prophet that as long as there are still those who do not violate a single part of their people who have changed the commandments of Allah, the Prophet must forgive and be tolerant (yajibu 'ala al-nabi saw al-'afw wa altasamuh ma'abum) because Allah likes those who do good. ${ }^{74}$

These verses also describe the condition of the Jewish and Christian communities at the time of the Prophet who continued to inhiraf (perpetuate the meaning), strife, enmity, and war as widely told in al-Baqarah, Āli 'Imrān, and al-

\footnotetext{
${ }^{72}$ Darwazah, VI., 472.

${ }^{73}$ Darwazah, VI., 472.

${ }^{74}$ Darwazah, IX., 73.
} 
Nisā' with clear explanations, ${ }^{75}$ such as in QS. al-Baqarah: 142 concerning the Jews who mock the Prophet because of the direction of the Qiblah of the Muslims with them and doubts about the movement of the Qiblah to the Kaaba.

Darwazah's opinion, as I stated above, answers the abrogation of peaceful verses by the 4 sword verses. Darwazah then quoted QS. al- Nisā': 90, which is the basis of asylum law in strengthening that argument, "except those who are allies of a people you are bound with in a treaty or those wholeheartedly opposed to fighting either you or their own people. If Allah had willed, He would have empowered them to fight you. So if they refrain from fighting you and offer you peace, then Allah does not permit you to harm them."

In this verse, the object of peace context also includes non-Muslim communities that ask for protection from other non-Muslim communities that have previously entered into peace agreements with Muslims. When interpreting this verse, Darwazah explained that in a narration (riwayah), the group that asked for asylum was Hilāl bin 'Uwaimir, who made a treaty with the Prophet, that he should act justly when one of his people came to the Prophet, and vice versa, or in the story of Saraqah ibn Mālik who made a treaty with the Prophet so as not to fight his people, and if the Quraysh went to Islam, they would also enter Islam because of a treaty with the Quraysh. ${ }^{76}$

In some narration, it is explained that the second group (who made a treaty with the Muslims) was the Ashjā' tribe, when they stopped in Madinah, then Prophet sent them loads of dates as a feast, and they conveyed the peace when Rasulullah asked for the purpose of their stop over, i.e. will not attack the Muslims and Bani Damrah, who are bound by their covenants. Then, Rasulullah accepted and made peace with the consideration.

Darwazah concluded that the context of QS. al-Nisā': 90 classify 3 kinds of non-Muslims in relation to the Muslim community, those are: (a) who held a covenant with the Muslim community; (b) who take refuge in communities involved in peace agreements; (c) those in neutral positions (avoiding war on Muslims and groups fighting Muslims $)^{77}$

The commentators narrate that this verse is abrogated by verse 5 QS. alTawbah. However, Darwazah denies this by arguing that the universality of the war order against all polytheistic communities after the month of Hurum in this verse there are exceptions, namely the polytheists who make peace treaties with Muslims until a certain time (Allah commands to perfect the period of agreement)

${ }^{75}$ Darwazah, IX., 74.

${ }^{76}$ Darwazah, XIII., 179.

77 Darwazah, XIII., 199. 
and other polytheists who are bound by the covenant to an indefinite period (as long as they are consistent with the agreement) as classified above. ${ }^{78}$

The qitäland peaceful verses, according to Darwazah, has been elaborated to various contexts and social conditions, whether when they descend in a state of tension with the infidels of Mecca or when interfaith people lives peacefully and respectfully in a place. Darwazah's opinion leads to the implications of the meaning of sword verses that in recent times have often been reduced by certain groups in legitimizing terrorism in the name of jihād. The sword verses that are understood as an obligation to fight the non-Muslim community are indiscriminately revealed in a condition of tension between the Muslims when the Prophet and his companions leaves for Mecca but were confronted by the infidels of Mecca until there was the Treaty of Hudaibiyah.

This context, exactly, is different from the social conditions at this time, where inter-religious communities can live together in harmony and peace. The principles of Islam as raḅmatan lil 'álamin are also stated in the Qur'an regarding the verses of tolerance as mentioned above. In fact, Allah also ordered the Holy Prophet to forgive those who broke the covenant (al-'afw wa al-safb). Likewise, in the context of kaffir which is often cited as the enemy of Islam, the word is not necessarily addressed absolutely to all infidels. The object of the qitäl commandment does not necessarily refer to them..

Some sword verses that are considered to abrogate the peaceful verses have been reviewed by Darwazah into other histories and contextual arguments, in order to classify Muslim relations with non-Muslims in QS. al-Nisā': 90. Thus, is the behavior of some group who often pursue jihād in Indonesia and intend to cut down all non-Muslims in accordance with the sword verses in the Qur'an and can be justified? Or has the qitäl command lost its sociological context in Indonesia?

To answer this question, it is important to reconsider Darwazah's opinion on QS. al-Tawbah: 41, concerning the orders of jihad, through the sacrifice of property or soul. Darwazah mentioned that the social background for the revelation of the verse was caused some people were reluctant to go to the Tâbūk war. In contrast to the character of the polytheists in Makkah who were openly hostile to the Prophet, the stubborn character of the disbelievers in Medina tended to be obscured because of the hypocrisy that grew in their hearts as when they were ordered to carry out the Tābūk war and a feeling of reluctance in the hearts of the munāfiq people arose, Allah sent QS. al-Tawbah: 41 as a rebuke for turning away from the provisions of Allah and His Messenger.

In addition to this verse, it is also mentioned in QS. al- Mumtahanah: 8 about the legality of doing good and fair to those who do not fight and expel Muslims from their country. That verse includes those who do not make peace

${ }^{78}$ Darwazah, XIII., 200. 
with the Muslims, who do not pay jizyah, even those who have fought with the Muslims before, but have made peace agreements like the Quraysh after the Treaty of Hudaibiyah. ${ }^{79}$

Based on Darwazah's views and the social context in Indonesia, it can be concluded at least 3 conclusion. First, the context of qitäl or jihād commands in sword verses cannot be understood and practiced rawly against the entire nonMuslim community. People who belong to three classifications of non-Muslims (who make covenants, who take refuge in communities involved in treaties, and are neutral) should not be fought under the pretext of the command of the sword verses. In relation to interfaith hostility caused by certain persons should be treated wisely about what is actually defended; syi'ar Allah or the interests of the factions?

Secondly, the peaceful verses revealed before the sword verses are not overturned because that verses is also muhkam and in a different context to the conditions when the sword verse was revealed. The apprehension of the peaceful verses is also undeniable because as in QS. al-Baqarah: 256, qad tabayyana al-rushd min al-ghayy, the text informs the muslims that non-Muslims have been filled with reason and can see clearly the straight religion and god willing. Ultimately, religious tolerance, forgiving people other than Muslims, and living in harmony with them is also a universal command for all Muslims in the world.

Third, socially, wars or clashes between religions should no longer be carried out. Because even at the time of the Prophet, he and his companions never provoked a war. In fact, if we understand the verses carefully, the sword verses that are often used by terrorists to legitimize their actions are actually far removed from the current context, that is when the people live peacefully between other religions.

\section{Conclusion}

Darwazah's perspective with the tartīb nurülì method was able to open "the barrier wall" between the sword verses and the context in which it was revealed. Sociologically, the sword verses contain orders of war against the communities referred to non-muslim. However, Darwazah refutes the opinions of the verses by presenting the facts and conditions that occurred when the verses of the sword came to the Prophet, such as the period of tension in the Hudaibiyah Agreement, the reluctance of a group of hypocrites to come down in the Tâbūk War, and others. This fact led Darwazah's view to the continued existence of peaceful verses because there was no contradiction between the verses, both textual and contextual.

${ }^{79}$ Darwazah, XIII., 276. 
Darwazah exegesis, that I call it a "window", helps generations who live long after the prophetic period to observe the process of preaching and the passage of verses, both sword verses and peaceful verses, so as to avoid the confusion of the meaning of the Qur'an. Darwazah's thoughts in this study can be reflected through a sociolinguistic approach, how the contextualization of language existence is implemented in an interactive space. The correlation of the sword verses is not an interpretation of the peaceful verses, but the dialectical method of the Qur'an in certain events from pre to the prophetic era which continues to experience ups and downs, so that the interpretation of a verse is not understood as it is without tracing the intermediary that is the cause. Verse down and examine its relationship with other verses that seem contradictory in the structure of reason.

Besides the discourse above, it can be concluded that Islam has the authority which is used as a reference in dealing with non-Muslim communities. However, more than that, Islam also teaches its adherents to clarify other verses in the Qur'an substantively before manifesting them in an open space because a partial understanding of one or two verses of the sword cannot be used as an argument in judging religion. As a result, the justification for violence can be reduced by promoting harmony that is formed through a complete understanding of the verses of the Qur'an.

\section{Bibliography}

'Ubayd, Abū. Kitāh Al-Nāsikh Wa Al-Mansūkeh. Edited by Mustafā 'Abd al-Qādir 'Atā.' Beirūt: Dār al-Kutub al-'Ilmiyah, 2006.

Al-Banna, Jamal. Jihad. t.tp: t.p, n.d. https://kutub.freesite.host/tag/البنال-البنال جهاد-pdf/.

Al-Dawoody, Ahmed Mohsen. "War in Islamic Law: Justifications and Regulations." University of Birmingham, 2009.

Al-Haytamī, Ibn Hajar. Tubfat Al-Mubtäj Bi Sharh Al-Minhäj. Mesir: Matba'at Mustafa Muhammad, n.d.

Al-Jawzī, Ibn. Nawäsikh Al-Qur'ān. Beirūt: Dar al-Kutub al-'Ilmiyyah, n.d.

Al-Khalidi, 'Abd al-Fattah. Ta'ríf Al-Dārisin Bi Manāhij Al-Mufassirin. Damaskus: Dār al-Qalam, 2002.

Al-Majlisī, Muhammad Bāqir. Bihār Al-Anwār Al-Kāmi'ah Li Al-Durar Akhbār AlAi’immah Al-Athār. Beirūt: Mu’assasat al-Wafā', 1983.

Al-Qurtubī, Abū Bakr. Al-Jāmi' Li Abkēm Al-Qur'ān. Riyāḍ: Dār 'Alam al-Kutub, 2003. 
Al-Sadūs̄i, Qatādah bin Di’āmah. "Kitāb Al-Nāsikh Wa Al-Mansūkh Fī Kitāb Allāh Ta'ālā,." In Silsilat Kutub Al-Näsikh Wa Al-Mansükh, 22. Beirūt: Mu'assasat al-Risālah, 1998.

Al-Salamah, Hibah Allah. Al-Näsikeh Wa Al-Mansükh. Kairo: Maktabat alMutanabbi, n.d.

Al-Suyūtī, Jalāl al-Dīn. Al-Durr Al-Manthūr Fì Al-Tafsìr Bi Al-Ma'thūr. Kairo: Markaz Hajr li al-Buhūth wa al-Dirāsāt al-'Arabiyyah wa al-Islāmiyyah, 2003.

—. Al-Itqān Fì Ulūm Al-Qur'Ān. Beirūt: Dār al-Fikr, n.d.

Ashūr, Muhammad Tāhir Ibn. Tafsìr Al-Tahrìr Wa Al-Tanwìr. Tunisia: Dār alTunisia, 1984.

Darwazah, Muhammad Izzat. Al-Tafsir Al-Hadith Tartīb Al-Suwar Hash Al-Nuzūl. Beirūt: Dar al-Gharb al-Islamī, 2000.

Fawaid, Ahmad. "Kontra Narasi Ekstremisme Terhadap Tafsir Ayat- Al- Dīn Al -Ma Hallī Dan Jalāl Al- Dīn Al - Suyūṭī,” 2019, 299. http://digilib.uinsby.ac.id/35892/2/Ahmad Fawaid_F53314039.pdf.

Fawaid, Ahmad, and Nafi'ah Mardlatillah. "Bias Ideologis Tafsir Hizb Al-Tahrīr." MAGHZA: Jurnal Ilmu Al-Qur'an Dan Tafsir 5, no. 2 (2020): 184-209. https://doi.org/10.24090/maghza.v5i2.4243.

Fikriyati, U. “Interpretasi Ayat-Ayat 'Pseudo Kekerasan': Analisis Psikoterapis Atas Karya-Karya Tafsir Hannān Laḥhām,” 2018. http://digilib.uinsby.ac.id/id/eprint/25789.

Haleem, M.A.S. Abdel. "Qur'anic 'Jihād': A Linguistic and Contextual Analysis." Journal of Qur'anic Studies 12 (2010): 147-66. https://doi.org/10.3366/e1465359110000999.

Halimi, Mahfuh. "Abrogation and the Verse of the Sword: Countering Extremists' Justification for Violence." Counter Terrorist Trends and Analyses Volume 9 (2017): 27-35.

Halverson, Jeffry R, R Bennett Furlow, and Steven R Corman. "How Islamist Extremists Quote the Qur'an." Arizona State University Center for Strategic Communication, 2012.

Hana, Rudy al. "Konsep Kafir Perspektif Izzat Darwazah Dan Implikasinya Pada

Realitas Kekinian.” ISLAMICA: Jurnal Studi Keislaman 14, no. 2 (2020): 171-93. 
Hātim, Ibn Abī. Tafsìr Al-Qur'ān Al-'Až̀m, Musnadan 'an Al-Rasūl Sallā Allāh 'Alayh $W$ a Sallam $W$ a Al-Sahäbah $W a$ Al-Täbi'ìn. Edited by As'ad Muhammad Al-Tayyib. Riyād: Maktabat Nizār Mustafā al-Bāz, 1997.

Ibn Kathīr. Tafsìr Al-Qur'àn Al-Aq̌im Juそ. I. Beirūt: Dār al-Kutub al-'Ilmiyyah, 2017.

Ibnu Kathir. Tafsir Al-Qur'an Al-Adhim Juz II. Beirut: Dar al-Kotob al-Ilmiyah, 2017.

Ibrahim, Zakyi. "A Sociopolitical Analysis of the Verses of Peace: Qur'an 8:6162.” International Journal on World Peace 30, no. 1 (2013): 89.

Islam, Tazul. "Christian-Muslim Relations: An Analysis of the Quranic Articulation of Christian Friendliness to Muslims." Al-Bayan: Journal of Qur'an and Hadith Studies 17 (2019): 24-37. https://doi.org/10.1163/22321969-12340068.

Rahma, Andita. "Polisi Tangkap Pelantun Azan Hayya Alal Jihad." TEMPO.CO, December 4, 2020.

Rokhman, Fathur. Sosiolinguistik: Suatu Pendekatan Pembelajaran Bahasa Dalam Masyarakat Multikultural. Graha Ilmu, 2013.

Safrodin, Safrodin. "Diskursus Naskh Ayat-Ayat Toleransi Oleh Ayat-Ayat Perang Dalam Al-Qur'an.” Jurnal THEOLOGIA 30, no. 1 (2019): 51-74. https://doi.org/10.21580/teo.2019.30.1.3206.

Shihab, M Quraish. Rasionalitas Al-Qur'an: Studi Kritis Atas Tafsir Al-Manar. Lentera Hati, 2006.

Sulaymān, Muqātil bin. Tafsìr Muqātil Bin Sulaymān. Beirūt: Dār al-Kutub al'Ilmiyyah, 2003.

Taufiq, Imam. AL-QUR'AN BUKAN KITAB TEROR. Yogyakarta: Bentang Pustaka, 2015.

Taymiyyah, Ibn. Al-Jawāb Al-Sahīh Li Man Baddala Din Al-Masīh. Riyād: Dār al'Āsimah, n.d.

Wardani, Wardani. Ayat Pedang Versus Ayat Damai: Menafsir Ulang Teori Naskh Dalam Al-Qur'an. Jakarta: Badan Diklat dan Litbang Agama Kementerian Agama, 2011.

Wijaya, Aksin. Sejarah Kenabian Dalam Perspektif Tafsir Nuzuli Mubammad Irzat Darwazah. Bandung: Mizan, 2016. 